\title{
PENERAPAN TEKNOLOGI DIGITAL MARKETING UNTUK MENINGKATKAN STRATEGI PEMASARAN SNACK TIWUL
}

\author{
Ni Putu Diah Puspitasari ${ }^{1}$,Ainun Dhiya'a Nabillah ${ }^{2}$, Reffan Bahari $^{3}$,Nanda Damar \\ Caksono $^{4}$, Mustika $^{5}$ \\ Program Studi Ilmu Komputer, Fakultas Ilmu Komputer, Universitas Muhammadiyah Metro ${ }^{1,3,4,5}$ \\ Program Studi Sistem Informasi, Fakultas Ilmu Komputer, Universitas Muhammadiyah Metro ${ }^{2}$ \\ Jl. Gatot Subroto No. 100 Metro Lampung \\ diahp3370@gmail.com ${ }^{l,}$ ainunbila184@gmail.com² reffann.bahari@gmail.com ${ }^{3}$, \\ nandadamarcaksono09@gmail.com ${ }^{4}$ dosen.mustika@gmail.com ${ }^{5}$
}

\begin{abstract}
Aisyiyah Family Economic Business Development (BUEKA) is a UMKM that produces tiwul snacks. The problem faced by BUEKA in the tiwul snack production process lies in the problem of marketing. To overcome these problems, a digital marketing system is built that serves to increase marketing of tiwul snacks. Digital marketing products that are built consist of e-commerce, social media, online marketplace, these three elements are integrated with each other. The research method used consists of four stages, namely analysis, design, implementation and testing. Digital marketing products that are proposed as alternative solutions offered to partners are simple and user friendly, this is to make it easier for BUEKA to use digital marketing that is built considering Bueka's human resources are stuttering technology (technologically). And if, BUEKA continues to use digital marketing products that are built on an ongoing basis, of course, there will be increased knowledge of partners regarding digital marketing technology, and will have an effect on increasing the spread of marketing of partner products to be wider so that sales will increase, and have an impact on higher profits.
\end{abstract}

\begin{abstract}
Abstrak- Bina Usaha Ekonomi Keluarga Aisyiyah (BUEKA) adalah UMKM yang memproduksi snack tiwul. Permasalahan yang dihadapi BUEKA dalam proses produksi snack tiwul terletak pada masalah pemasaran. Untuk mengatasi permasalahan tersebut, maka dibangun sistem digital marketing yang berfungsi untuk meningkatkan pemasaran snack tiwul. Produk digital marketing yang dibangun terdiri dari $e$-commerce, social media, marketplace online, ketiga elemen tersebut terintegrasi satu sama lain. Metode penelitian yang digunakan terdiri dari empat tahapan yaitu analisis, desain, implementasi dan testing. Produk digital marketing yang diusulkan sebagai alternative solusi yang ditawarkan kepada mitra tergolong sederhana dan user friendly, hal tersebut untuk mempermudah pihak BUEKA untuk menggunakan digital marketing yang dibangun mengingat SDM Bueka tergolong gagap teknologi (gaptek). Dan apabila, BUEKA terus menggunakan produk digital marketing yang dibangun secara berkelanjutan, tentunya akan meningkatnya pengetahuan mitra mengenai teknologi digital marketing, dan akan berpengaruh pada meningkatnya jangkauan sebar pemasaran produk mitra menjadi lebih luas sehingga penjualan akan ikut meningkat, dan berdampak kepada profit yang lebih tinggi.
\end{abstract}

Keyword: Digital Marketing, E-commerce, Snack Tiwul, Marketplace, Sosial Media

\section{PENDAHULUAN}

Lampung merupakan salah satu wilayah yang cocok untuk ditanami ubi kayu sehingga hal ini mendorong masyarakat Lampung untuk memilih usaha pertanian ubi kayu sebagai mata pencaharian mereka. Oleh sebab itu, Provinsi Lampung menjadi salah satu sentra produksi ubi kayu di Indonesia yang pada tahun 2015 memiliki luas panen untuk komoditi ubi kayu seluas 301.684 hektar dan menghasilkan produksi ubi kayu sebesar 8.038.953 ton dengan produktivitas 26,24 ton/ha atau sekitar [1]

Salah satu kecamatan yang menghasilkan ubi kayu terbanyak di Lampung adalah kecamatan Bumi Ratu Nuban. Tingginya produksi ubi kayu tersebut dimanfaatkan oleh keluarga ibu Solikhah untuk berkreativitas dan menginovasi ubi kayu agar bernilai jual lebih tinggi dibandingkan jika menjual ubi kayu mentah. Inovasi olahan ubi kayu tersebut menjadi aneka snack tiwul seperti jipang dengan berbagai rasa. Produk Ibu Solikhah memiliki nama usaha dagang BUEKA yang merupakan singkatan dari Bina Usaha Ekonomi
Keluarga Aisyiyah Yang diproduksi oleh Kelompok Wanita Tani (KWT) Kenanga. Produk BUEKA memiliki Kode Pangan Industri Rumah Tangga atau PIRT No: 215 180594026221.

Berdasarkan observasi dan wawancara ada beberapa permasalahan yang dihadapi BUEKA yaitu terletak pada aspek bahan baku, tenaga kerja dan pemasaran. Dari ketiga permasalahan tersebut, permasalahan pemasaran menjadi permasalahan prioritas. Pada aspek pemasaran BUEKA hanya mengandalkan pemasaran konvensional yaitu dari mulut ke mulut, sehingga jangkauan pasar relatif masih sedikit. Kegiatan pemasaran belum menggunakan teknologi, dikarenakan tenaga kerja BUEKA masih tergolong gagap teknologi (gaptek) belum memaksimalkan penggunaan smartphone dan fasilitas internet yang tersedia. Alternatif solusi yang dapat membantu mengatasi permasalahan prioritas tersebut adalah perlu diterapkannya teknologi digital marketing sebagai strategi pemasaran snack tiwul BUEKA.

Digital marketing adalah kegiatan promosi dan pencarian pasar melalui media digital secara online dengan 
memanfaatkan berbagai sarana misalnya jejaring sosial. Dunia maya kini tak lagi hanya mampu menghubungkan orang dengan perangkat, namun juga orang dengan orang lain di seluruh penjuru dunia. Digital marketing yang biasanya terdiri dari pemasaran interaktif dan terpadu memudahkan interaksi antara produ-sen, perantara pasar, dan calon konsumen. Di satu sisi, digital marketing memudahkan pebisnis memantau dan menyediakan segala kebutuhan dan keinginan calon konsumen, di sisi lain calon konsumen juga bisa mencari dan mendapatkan informasi produk hanya dengan cara menjelajah dunia maya sehingga mempermudah proses pencariannya. Pembeli kini semakin mandiri dalam membuat keputusan pembelian berdasarkan hasil pencariannya. Digital marketing dapat menjangkau seluruh masyarakat di manapun mereka berada tanpa ada lagi batasan geografis ataupun waktu. [2]

Produk digital marketing yang dibangun sebagai strategi pemasaran snack tiwul meliputi website penjualan (e-commerce) snack tiwul dan sosial media yang terintegrasi dengan $e$-commerce.

\section{A. E-Commerce}

Menurut Julisar, pemanfaatan internet memungkinkan Usaha Kecil dan Menengah melakukan pemasaran dengan tujuan pasar global, sehingga peluang menembus ekspor sangat mungkinImplementasi dari $e$ commerce juga harus didukung dengan adanya sistem pembayaran danpemenuhan pemesanan dari pembeli, yaitu suatu portal yang berisikan content dari perusahaantersebut.Sarana yang diperlukan untuk membangun hal-hal tersebut di atas dikategorikan dalam einfrastrusture (umumnya berisikan sistem yang mengintegrasikan bagian-bagian yang salingberhubungan, hosting, masalah keamanan, jaringan nir-kabel, network), e-process (umumnya masalahpembayaran dan logistic), e-market (umumnya masalah pemasaran dan advertising), $e$ communities(masalah audience dan partner bisnis), $e$ service (Customer Relationship Management, PartnershipRelationship Management dan pelayananpelayanan yang lain), e-content (didukung oleh operatorpenyedia content). Semua bentuk tersebut harus ada untuk mendukung kegiatan dari e-commerce.[3]

\section{B. Media Sosial Berbasis Bisnis}

Menurut Priambada, media sosial memiliki potensi yang lumayan bagus, sangat bagus/baik, potensi yang sangat besar / sangat berpotensi, sangat berpeluang / menjanjikan dalam mendukung UKM. Potensi akan terus meningkat pada masa yang akan datang. Media sosial memiliki potensi yang baik untuk mempercepat informasi pemasaran, testimoni dan masukan dari konsumen, mempererat hubungan dengan konsumen dan membantu menjangkau semua kalangan.[4]

Tabel 1. Alasan Media Sosial dianggap Paling Efektif mendukung UKM

\begin{tabular}{|c|c|}
\hline $\begin{array}{c}\text { Media } \\
\text { Sosial } \\
\end{array}$ & $\begin{array}{c}\text { Alasan Dianggap sebagai Media yang } \\
\text { Paling Efektif }\end{array}$ \\
\hline Facebook & $\begin{array}{l}\text { "Jangkauan cukup luas dan banyak } \\
\text { penggunanya", "karena lebih mudah dan } \\
\text { banyak orang yang telah memiliki akun } \\
\text { Facebook", "cepat berinteraksi dengan } \\
\text { orang banyak" }\end{array}$ \\
\hline Whatsapp & $\begin{array}{l}\text { "Facebook dan Whatsapp, karena lebih } \\
\text { luas dan langsung pada (produk saya)", } \\
\text { "FB, WA karena hampir semua teman di } \\
\text { FB \& kontak WA adalah kenalan", "WA } \\
\text { semua pake. Gambar dan videocall } \\
\text { lancar" }\end{array}$ \\
\hline Instagram & $\begin{array}{l}\text { "Instagram, sesuai dengan selera masa } \\
\text { muda masa kini", "instagram..karena } \\
\text { banya foto produk yang bisa langsung } \\
\text { dilihat sama customer", "instagram, } \\
\text { selain karena lagi booming, instagram } \\
\text { juga punya interface yang simple dan } \\
\text { mudah dimengerti pengguna". }\end{array}$ \\
\hline Website & $\begin{array}{l}\text { "Website, karena informasi yang } \\
\text { disajikan luas sekali kontennya (gambar } \\
\text { produk, lokasi, dll) termasuk kontak". }\end{array}$ \\
\hline
\end{tabular}

\section{Aplikasi Marketplace}

E-marketplace adalah sebuah sistem informasi antar organisasi dimana pembeli dan penjual di pasar mengkomunikasikan informasi tentang harga, produk dan mampu menyelesaikan transaksi melalui saluran komunikasi elektronik. Dengan melalui internet para penjual dimudahkan dalam melakukan promosi dan memasarkan produknya dalam jangkauan yang lebih luas [5].

Shopee ialah platform belanja berbasis online yang menyediakan beragam macam produk penjualan mulai dari elektronik, perlengkapan rumah tangga, pakaian, aksesoris hingga fashion. Selain menyediakan berbagai macam produk, keunggulang lain dari Shopee yakni pembeli dapat mengembalikan barang atau dana apabila barang yang diterima tidak sesuai dengan yang diinginkan. Pengguna juga dapat menemukan barang dengan mudah pada kolom pencarian hanya dengan memasukan gambar barang yang sedang dicari. Dan Shopee juga menyediakan fitur gratis ongkir untuk pengiriman barang. Dengan menduduki urutan ke empat pada kategori pencarian e-commerce yang paling diminati oleh pengguna dalam Top 40 e-commerce dengan jumlah 34.510 .800 pengunjung setiap bulannya. [6]

Menurut Rohandi, marketplace Tokopedia dan Bukalapak memiliki kriteria penilaian baik dengan perbedaan nilai total rata-rata secara keseluruhan tidak terpaut terlalu jauh hanya $0,95 \%$, dimana Tokopedia memiliki kinerja yang sedikit lebih unggul daripada Bukalapak dengan nilai 75,60\% dan 74,65\%. Responden

166 | http://www.jurnal.umb.ac.id/index.php/JSAI 
memberikan penilaian yang hampir seimbang sehingga proses layanan yang berikan serta tingkat kemajuan teknologi untuk selalu diupdate yang disesuaikan dengan perkembangannya termasuk masalah database dan kegiatan operasional web yang harus melakukan perawatan terhadap para stakeholder dan shareholder yang dimiliki oleh masing-masing marketplace.[7]

\section{METODEPENELITIAN}

Metode penelitian yang digunakan terdiri dari beberapa tahapan, gambar 1 adalah gambar tahapan penelitian.

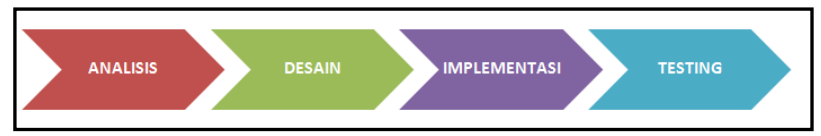

Gambar 1. Tahapan Penelitian

Berdasarkan gambar 1, maka uraian dari tahapan penelitian ini meliputi:

a) Analisis

Analisis yang dilakukan dalam tahapan ini adalah mengidentifikasi permasalahan yang ada dan memberikan solusi terhadap masalah yang sudah teridentifikasi tersebut.

ada tiga permasalahan yang dihadapi oleh BUEKA dalam produksi snack tiwul. Analisis permasalah termuat didalam tabel 2.

Tabel 2. Analisis Masalah

\begin{tabular}{ll}
\hline Identifikasi Masalah & \multicolumn{1}{c}{ Solusi } \\
\hline BAHAN BAKU & Mencari sumber bahan \\
Langkahnya bahan & baku dari daerah di \\
bakutiwul (ubi kayu) & luar kecamatan Bumi \\
yang disebabkan & Ratu Nuban, hal ini \\
petani sekitar sudah & menjadi biaya \\
terikat kontrak dengan & tambahandalam \\
perusahaan tapioka & produksi dikarenakan \\
yang ada di Provinsi & ongkos angkut menjadi \\
Lampung. & lebih tinggi. \\
TENAGA KERJA & Memanfaatkan anggota \\
Tahapan olahan tiwul & keluarga untuk \\
menjadi snack yang & membantu dalam \\
mampu & proses olahan tiwul. \\
mempertahankan & \\
kualitas produk, & \\
apabila dikerjakan & \\
oleh tenaga kerja yang & \\
tidak piawai tentu saja & \\
akan mengakibatkan & \\
kerugian bagi & \\
BUEKA. & \\
PEMASARAN & Teknologi Digital \\
pemasaran BUEKA & Marketing, yang terdiri \\
hanya mengandalkan & dari e-commerce, \\
kemasaran & sosial media berbasis \\
bonvensional & \\
\hline
\end{tabular}

dari mulut ke mulut, marketplace online. sehingga jangkauan pasar relatif masih sedikit. Kegiatan pemasaran belum menggunakan teknologi, dikarenakan tenaga kerja BUEKA masih tergolong gagap teknologi (gaptek) belum memaksimalkan penggunaan smartphone dan fasilitas internet yang tersedia.

b) Desain

Tahapan ini melakukan desain terhadap pembangunan e-commerce untuk pemasaran snack tiwul.

Ada beberapa desain yang perlu dilakukan sebelum tahap implementasi kode. Diantara desain yang dilakukan adalah desain halaman pada gambar 2 dan desain detail produk pada gambar 3 .

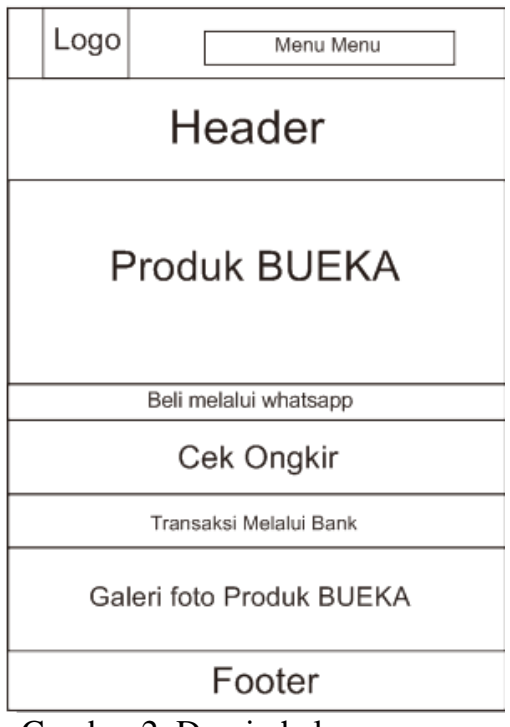

Gambar 2. Desain halaman menu 


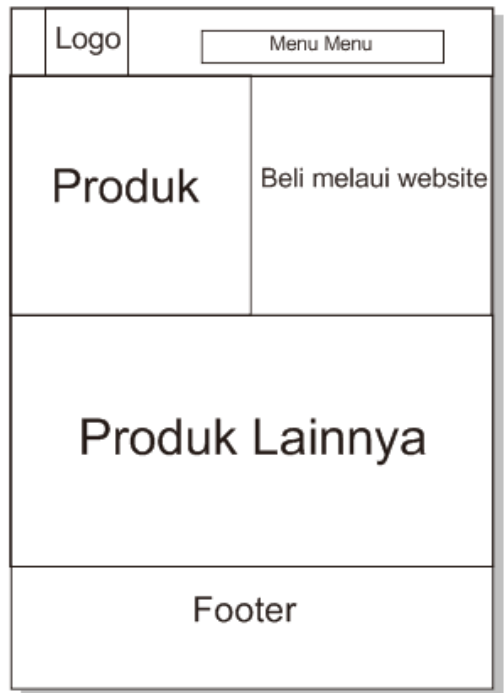

Gambar 3. Desain detail produk

Untuk sosial media dan aplikasi marketplace tidak memerlukan desain, hanya memerlukan nama akun yang akan dibuat, photo produk dan informasi produk lainnya.

c) Implementasi

Tahapan ini mengimplementasikan desain pada tahapan sebelumnya menjadi sebuah e-commerce yang dapat digunakan. Selain itu juga implementasi dilakukan dalam pembuatan akun sosial berbasis bisnis yaitu instagram, facebook dan whatsapp. Untuk aplikasi marketplace yang digunakan adalah shopee dan tokopedia.

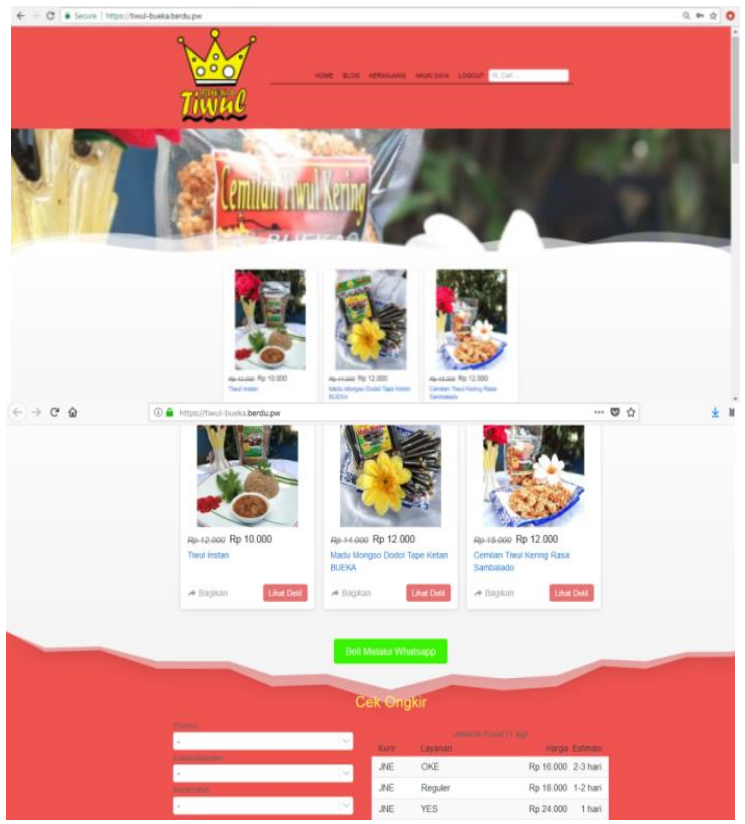

Gambar 4. Website Bueka Tiwul

Sedangkan untuk sosial media yang terdiri instagram, facebook dan whatsapp, seperti gambar 5 dan gambar 6.

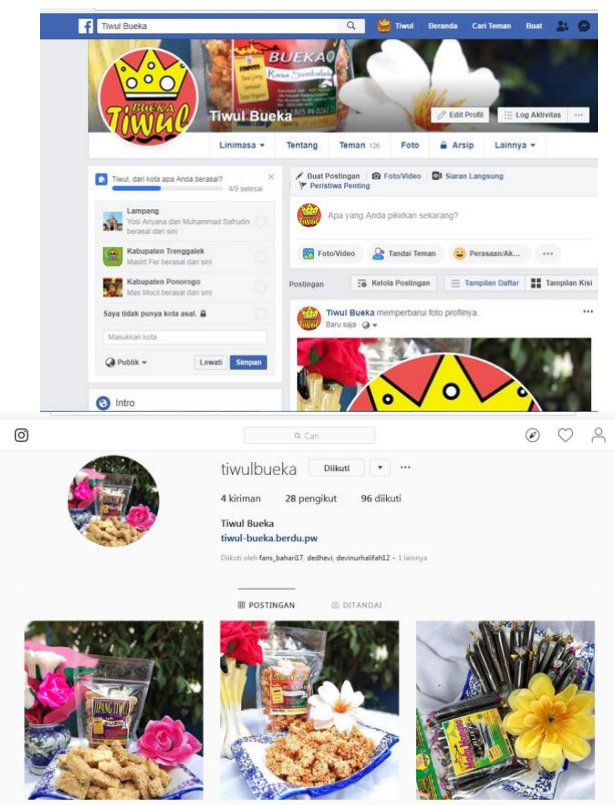

Gambar 5. Facebook dan Instagram Bueka Tiwul

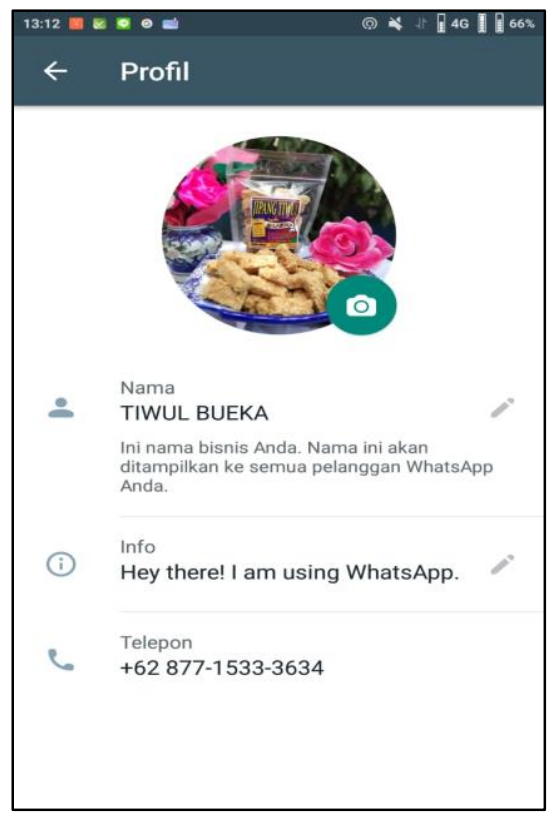

Gambar 6. Whatsapp bisnis Tiwul Bueka

Pemesanan dan pembelian snack tiwul selain dapat dilakukan dari website, instagram, facebook, whatsapp diperbanyak lagi dengan cara memesan pada aplikasi marketplace online yaitu shopee dan tokopedia. Gambar 7 adalah shopee dan tokopedia tiwul bueka. 


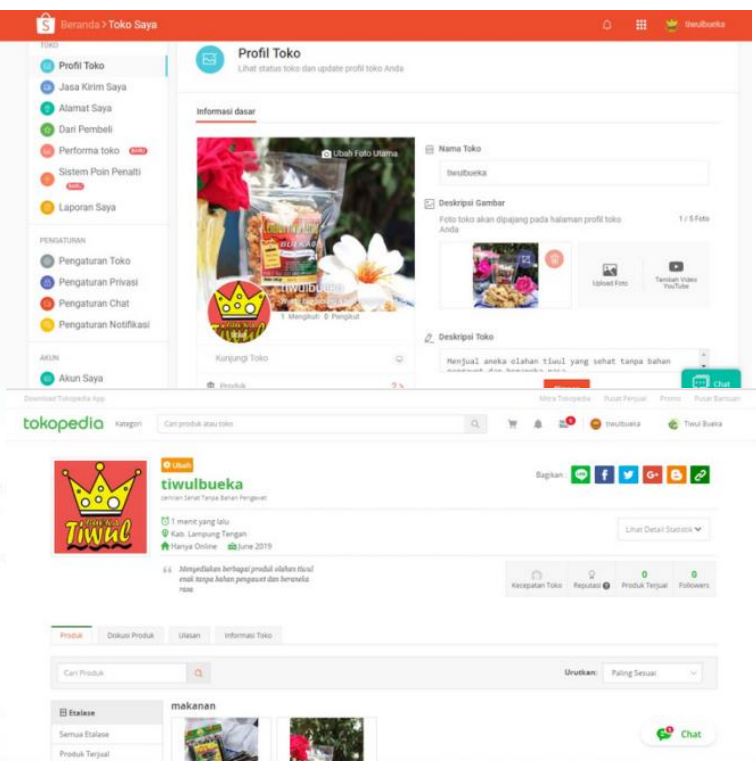

Gambar 7. Marketplace Online Tiwul Bueka

d) Testing

Tahapan ini melakukan uji coba terhadap ecommerceyang dibangun, dan memastikan ecommerce terkoneksi ke sosial media bisnis yang dibuat.

Digital marketing yang terdiri dari e-commerce, social media dan marketplace online dirancang sedemikian rupa untuk terintegrasi satu dengan yang lainnya. Salah satu hal yang tidak terpisahkan dari digital marketing adalah promosi/iklan.

Pengujian yang dilakukan adalah memastikan apakah menu atau fitur dari e-commerce bueka tiwul berfungsi sebagaimana fungsinya sesuai dengan scenario yang diharapkan. Tabel 3 adalah tahap pengujian fungsional e-commerce dengan menggunakan teknik blackbox testing.

Tabel 3. Pengujian Blackbox

\begin{tabular}{|c|c|c|c|}
\hline $\begin{array}{c}\text { Hal yang } \\
\text { diuji }\end{array}$ & Skenario & $\begin{array}{r}\text { Hasil yang } \\
\text { diharapkan }\end{array}$ & $\begin{array}{c}\text { Hasil } \\
\text { pengujian }\end{array}$ \\
\hline \multirow[t]{2}{*}{ Login } & $\begin{array}{l}\text { Input Login } \\
\text { (Data } \\
\text { Benar) }\end{array}$ & $\begin{array}{l}\text { User masuk ke menu } \\
\text { utama }\end{array}$ & Berhasil \\
\hline & $\begin{array}{l}\text { Input Login } \\
\text { (Data } \\
\text { Salah) }\end{array}$ & $\begin{array}{l}\text { Notifikasi } \quad \text { Error } \\
\text { gagal }\end{array}$ & Berhasil \\
\hline Detail Produk & $\begin{array}{l}\text { Klik button } \\
\text { Lihat Detail }\end{array}$ & $\begin{array}{l}\text { Menampilkan } \\
\text { informasi produk } \\
\text { dan terdapat dua opsi } \\
\text { untuk beli sekarang } \\
\text { atau tanbah ke } \\
\text { keranjang }\end{array}$ & Berhasil \\
\hline Pembelian & $\begin{array}{l}\text { Klik button } \\
\text { beli } \\
\text { sekarang } \\
\text { (Data } \\
\text { Lengkap) }\end{array}$ & $\begin{array}{l}\text { Menampilkan form } \\
\text { informasi pembeli, } \\
\text { isian data pembeli } \\
\text { semua harus diisi } \\
\text { dan benar, dapat } \\
\text { lanjut ke metode } \\
\text { pengiriman }\end{array}$ & Berhasil \\
\hline
\end{tabular}

\begin{tabular}{|c|c|c|c|}
\hline & $\begin{array}{l}\text { Klik button } \\
\text { beli } \\
\text { sekarang } \\
\text { (Data Tidak } \\
\text { Lengkap) }\end{array}$ & $\begin{array}{l}\text { Menampilkan form } \\
\text { informasi pembeli, } \\
\text { isian data pembeli } \\
\text { tidak lengkap diisi, } \\
\text { mendapat notifikasi } \\
\text { pengisian data harus } \\
\text { lengkap }\end{array}$ & Berhasil \\
\hline $\begin{array}{l}\text { Metode } \\
\text { Pengiriman }\end{array}$ & $\begin{array}{l}\text { Pemilihan } \\
\text { jasa } \\
\text { ekspedisi }\end{array}$ & $\begin{array}{l}\text { Menampilkan } \\
\text { pilihan ekspedisi } \\
\text { yang digunakan, dan } \\
\text { tombol lanjutkan } \\
\text { aktif }\end{array}$ & berhasil \\
\hline $\begin{array}{l}\text { Metode } \\
\text { Pembayaran }\end{array}$ & $\begin{array}{l}\text { Pemilihan } \\
\text { jenis } \\
\text { metode } \\
\text { pembayara } \\
\text { n }\end{array}$ & $\begin{array}{l}\text { Menampilkan } \\
\text { pilihan metode } \\
\text { pembayaran }\end{array}$ & Berhasil \\
\hline $\begin{array}{l}\text { Beli Melalui } \\
\text { Whatsapp }\end{array}$ & $\begin{array}{l}\text { Klik Button } \\
\text { Beli } \\
\text { melalui } \\
\text { whatsapp }\end{array}$ & $\begin{array}{l}\text { User langsung dapat } \\
\text { chat via whatsapp } \\
\text { dengan bueka tiwul }\end{array}$ & Berhasil \\
\hline Cek Ongkir & $\begin{array}{l}\text { Klik button } \\
\text { cek ongkit }\end{array}$ & $\begin{array}{l}\text { Aplikasi dapar } \\
\text { memprediksi biaya } \\
\text { kirim melalui alamat } \\
\text { dan beratnya } \\
\text { pemesanan }\end{array}$ & Berhasil \\
\hline $\begin{array}{l}\text { Link } \\
\text { Instagram }\end{array}$ & $\begin{array}{l}\text { Klik icon } \\
\text { instagram }\end{array}$ & $\begin{array}{l}\text { Terkoneksi langsung } \\
\text { ke halaman } \\
\text { instagram tiwul } \\
\text { bueka }\end{array}$ & Berhasil \\
\hline $\begin{array}{l}\text { Link } \\
\text { Facebook }\end{array}$ & $\begin{array}{l}\text { Klik icon } \\
\text { Facebook }\end{array}$ & $\begin{array}{l}\text { Terkoneksi langsung } \\
\text { dengan halaman } \\
\text { instragram tiwul } \\
\text { bueka }\end{array}$ & Berhasil \\
\hline
\end{tabular}

\section{HASIL DAN PEMBAHASAN}

Sesuai dengan tujuan penelitin ini adalah dibangunnya produk digital marketing, yang terkoneksi antara website dan social media, sehingga pembeli mendapatkan kemudahan untuk memesan snack tiwul. Berikut hasil simulasi integrasi digital marketing.

a) Digital marketing melalui social media

Salah satu kekuatan dari digital marketing adalah pemanfaatan promosi dari social media. Akun instgaram yang sudah dibuat, didalam informasi instagram tersebut sudah dicantumkan link url website tiwul bueka. Seperti tampak pada gambar 7 .

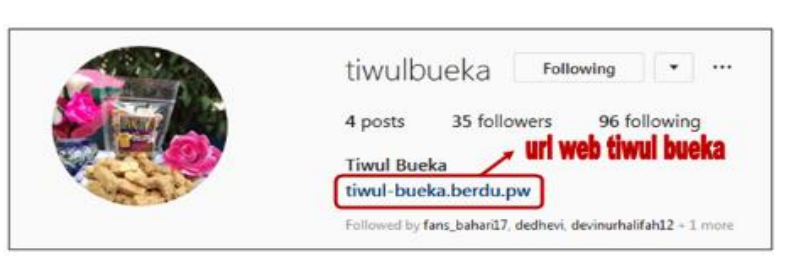

Gambar 7. Digital marketing melalui social media

Didalam website tiwul bueka, juga diberikan link social media yang tujuannya adalah memberikan berbagai alternative cara kepada konsumen dalam proses pemesanan. Karena berdasarkan tabel 1, konsumen memiliki alasan tersendiri dalam menggunakan media belanja online. Gambar 8 adalah halaman web yang dapat terkoneksi ke social media tiwul bueka. 


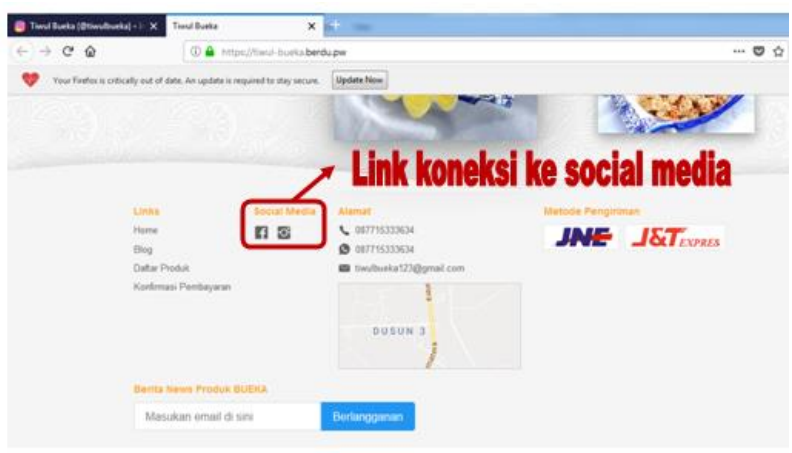

Gambar 8. Halaman web yang dapat terkoneksi dengan social media

b) Digital marketing melalui aplikasi chatting (Fast Respon)

Pada halaman website tiwul bueka, juga tersedia link untuk memesan secara langsung kepada penjual melalui aplikasi whatsapp, opsi ini akan tergolong fast respon. Gambar 9 adalah Halaman web yang dapat terkoneksi ke nomor whatsapp tiwul bueka.

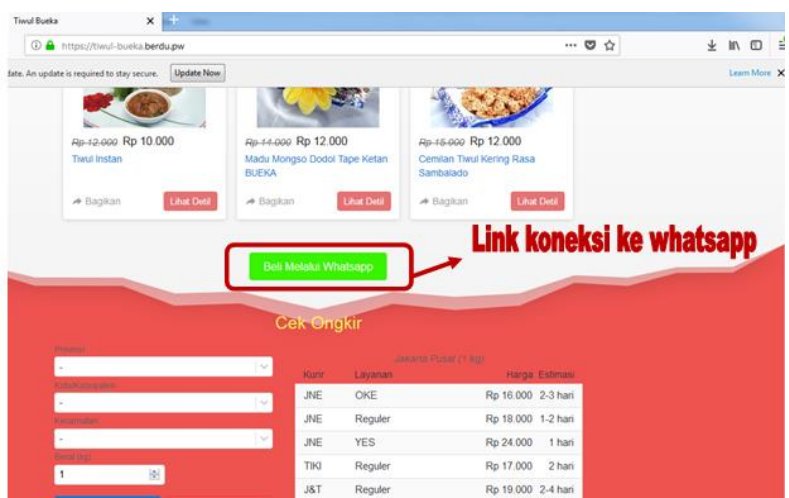

Gambar 9. Halaman web yang dapat terkoneksi ke whatsapp

Ketika pelanggan mengklik button Beli di Whatsapp maka akan langsung terkoneksi dengan pesan otomatis whatsapp tiwul bueka, seperti gambar 10.

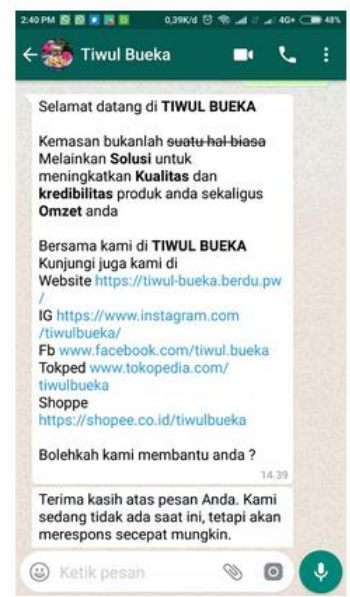

Gambar 10. Whatsapp bisnis Tiwul Bueka

\section{KESIMPULAN}

Permasalahan prioritas yang dihadapi BUEKA dalam produksi olahan tiwul adalah terletak pada pemasaran. Peranan teknologi informasi dapat menjadi alternative solusi BUEKA yaitu dibangunnya digital marketing, yang terdiri dari e-commerce, social media berbasis bisnis dan aplikasi marketplaceonline.

Produk digital marketing yang diusulkan sebagai alternative solusi yang ditawarkan kepada mitra tergolong sederhana dan user friendly, hal tersebut untuk mempermudah pihak BUEKA untuk menggunakan digital marketing yang dibangun mengingat SDM Bueka tergolong gagap teknologi (gaptek). Dan apabila, BUEKA terus menggunakan produk digital marketing yang dibangun secara berkelanjutan, tentunya akan meningkatnya pengetahuan mitra mengenai teknologi digital marketing, dan akan berpengaruh pada meningkatnya jangkauan sebar pemasaran produk mitra menjadi lebih luas sehingga penjualan akan ikut meningkat, dan berdampak kepada profit yang lebih tinggi.

\section{DAFTAR PUSTAKA}

[1] Badan Pusat Statistik. 2016. Tentang Produktivitas Ubi Kayu Menurut Provinsi di Indonesia. BPS.

[2] Purwana Dedi,dkk, 2017. Pemanfaatan Digital Marketing Bagi Usaha Mikro, Kecil, dan Menengah (UMKM) Di Kelurahan Malaka Sari Duren Sawit. Jakarta: Universitas Negeri Jakarta.

[3] Julisar\&Miranda Eka, 2013. Pemakaian E-Commerce untuk Usaha Kecil dan Menengah Guna Meningkatkan Daya Saing. Jakarta:Binus University.

[4] Priambada Swasta, 2017.Potensi Media Sosial bagi Usaha Kecil dan Menengah (UKM) di Malang Raya. Malang:Universitas Brawijaya.

[5] Rahmadi, dkk, 2015. Pengembangan Modul Freemium Aplikasi Tell-Us (Telkom University Store) Menggunakan Metode Iterative Incremental dan Framework Laravel. Bandung: Universitas Telkom.

[6] Meidita, Yusrini, dkk. 2018. Pengaruh Kualitas 170 | http://www.jurnal.umb.ac.id/index.php/JSAI 
Layanan Terhadap Kepuasan, Kepercayaan dan Loyalitas pelanggan pada E-Commerce (Studi Kasus: Shopee). Malang: Universitas Brawijaya.

[7] Rohandi, Mochamat Malik Akbar, 2017. Effectiveness C2C E-Commerce Media in Bandung (Case Study at Tokopedia.com and Bukalapak.com). Bandung: Universitas Islam Bandung. 